\title{
Relación entre la tenacidad a flexión y la energía de impacto en hormigones de alta resistencia reforzados con fibras (HSFRC)
}

\author{
Relationship between flexural toughness energy and \\ impact energy of high strength fiber reinforced concrete \\ (HSFRC)
}

Fecha de recepción: 6-VI-00
Fecha de aceptación: 3-XI-(00

\section{SUMMARY}

A simple, economical and practical impact resistance test method has been developed for high strength fiber reinforced concrete (HSFRC). The results indicated that there is a logarithmic relation between flexural toughness energy $\left(E_{r T}\right)$ and impact energy $\left(E_{l}\right)$ for FRC. In this study, three different aspect ratios of hooked-end fibers, namely, 30/0.50; 60/0.80 and 50/0.60 length/diameter $(\mathrm{mm} / \mathrm{mm})$ were used. Fibers were added to concrete in four different volume percentages of $0.5,1.0,1.5$ and $2.0 \%$. From the results it can be said that fibers in high strength concrete improve impact resistance and flexural toughness of concrete. Also a good correlation between flexural toughness energy and impact energy has been established.

\section{INTRODUCCIÓN}

El hormigón de alta resistencia se define como un hormigón con resistencia a compresión en probeta cilíndrica por encima de los límites ahora existentes en los códigos nacionales, próximo a $60 \mathrm{MPa}$, y supcrior a $130 \mathrm{MPa}$ que es prácticamente el límíte máximo establecido para hormigones con aditivos (1). El hormigón de alta resistencia es más quebradizo que el hormigón normal. Con el fin de superar y reducir esta fragilidad, sc han añadido fibras al hormigón (hasta una

\section{INTRODUCTION}

High strength concrete is defined as concrete having compressive cylinder strength above the present existing limits in national codes, i.e. about $60 \mathrm{MPa}$, and up to $130 \mathrm{MPa}$, the practical upper limit for concretes with ordinary aggregates (1). High strength concrete is more brittle than normal concrete; the higher the compressive strength of concrete the lower its ductility. In order to overcome and reduce the brittleness, fibers may be added to 
fracción del 2\% del volumen, e incluso, mayor) para formar un compuesto conocido como hormigón reforzado con fibra (2). La ventaja de la fibra de acero en el hormigón viene dada por la resistencia al impacto o la resistencia dinámica, que es mucho más alta que en un hormigón normal, además de mejorar otras propiedades mecánicas del hormigón de alta resistencia, como pueden ser la tenacidad y la resistencia a tracción. La definición de tenacidad es una medida de la capacidad de absorción de cnergía, y se utiliza para caracterizar las posibilidades que posee el hormigón reforzado con fibras de resistencia a la fractura, cuando éste está sujeto a cargas estáticas, dinámicas y de impacto. La tenacidad, por cuanto a la capacidad de absorción de la encrgía se refiere, puede calcularse como el área bajo la curva de carga-flecha a flexión, que es la energía total absorbida antes de completarse la separación de la mucstra.

Una de las posibilidades que existen para aumentar la resistencia a las cargas de impacto es la incorporación en el hormigón de diversos tipos de fibras distribuidas al azar (3). Como ejemplo podemos citar la resistencia al impacto en un hormigón, que con un $2 \%$ de contenido de fibra en volumen, resultó ser superior en un $730 \%$ a la del hormigón sin esa adición (4). La prueba se realizó con hormigón refractario al que se añadieron fibras de acero con un porcentaje del $55 \%$, sin utilizar humo de sílice. En estos ensayos, se utilizó, asimismo, un aparato de comprobación manual de impactos, con 4,54 $\mathrm{kg}$ de peso y 447,0 $\mathrm{mm}$ de altura de caída. Algunos investigadores $(5,6,7)$ utilizan aparatos de impacto recomendados por el Comité ACI 544 (8). En otro estudio (9), se pudo constatar que las fibras de plástico también poseen una significativa importancia por cuanto se refiere a la resistencia al impacto en el hormigón. La adición de humo de sílice en un porcentaje de entre el 5 y el $10 \%$ del peso del cemento, aumenta, incluso todavía más, la resistencia al impacto, debido a que mejora la dispersión en la fibra y la unión entre las fibras y el hormigón.

La resistencia al impacto precisa de una medición rápida y fidedigna, importante en aquellas estructuras que esten sujetas a cargas dinámicas, como, por ejemplo, el impacto de objetos en edificios industriales y pistas de aterrizaje en aeropuertos, así como impactos de proyectiles o impulsos, como ráfagas de aire, terremotos u olas marinas.

El objetivo del presente trabajo es determinar una relación entre la tenacidad y resistencia al impacto de hormigones reforzados con fibras (HSFRC),

comparandolos entre sí, ya que estas dos propiedades son una medida de la capacidad de absorción del material, y la resistencia al impacto está relacionada con la tenacidad y la capacidad de deformación (10). La energía de impacto the concrete (up to volume fraction of $2 \%$ and even greater) to form a composite known as fiber reinforced concrete (2). The benefits of steel fiber reinforced concrete are impact resistance or dynamic toughness that is much higher than that of plain concrete, improve some other mechanical properties of high-strength concrete such as flexural toughness and tensile strength. Toughness is a measure of energy absorption capacity, and it is used to characterize the ability of FRC to resist fracture when subjected to static, dynamic and impact loads. Toughness or energy absorption capability can be calculated from the area under the load-deflection curve in flexure, which is the total energy absorbed prior to complete separation of the specimen.

One way to improve the resistance of concrete to impact loading is by incorporation in the concrete of randomly distributed discrete fibers (3). For instance, the impact strength at full failure of concrete having $2.0 \%$ fiber content by volume was found to be $730 \%$ higher than that of plain concrete (4). The test was done on refractory concrete by adding steel fibers having an aspect ratio of 55\%; no silica fume was used. In these tests, a manually operated impact tester having a $4.54 \mathrm{~kg}$ weight with $457.0 \mathrm{~mm}$ drop height was used. Other researchers $(5,6,7)$ have used the impact apparatus, which is recommended by the ACI Committee 544 (8). In another study (9) it was found that, plastic fibers also significantly enhance impact resistance of concrete. Addition of silica fume at 5 and $10 \%$ by weight of cement increased the impact resistance even more due to the improvement in fiber dispersion and bond between fibers and concrete.

Impact resistance needs to be measured easily and reliably where it is important in structures subjected to dynamic loads arising from impulses due to falling objects in industrial buildings and airport runways, impact by missiles, impulsive loads due to air blasts, earthquakes and ocean waves.

The objective of the present work is to produce a relationship between flexural toughness and impact resistance of HSFRC composites by comparing them since these two properties are a measure of the energy absorption capacity of the material, and since impact resistance of the material is related to its toughness and strain capacity (10). Impact energy 
se determina a través de una máquina de ensayo de impacto por martinete, sencilla y económica, de la que hablaremos en este trabajo, y que puede ser utilizada también in situ. Además, se cmpleó otra máquina de circuito cerrado, muy sofisticada, capaz de realizar ensayos de flexo-compresión servo controlada (200 kN carga máxima de flexión), que se utiliza para determinar la tenacidad a flexión en los HSFRC. En esta investigación, los autores han intentado establecer una relación entre estas dos importantes propiedades.

\section{PROGRAMA EXPERIMENTAL}

\subsection{Hormigón}

La relación de agua-cemento utilizada para esta investigación fue de 0,35 . Se usaron, en todo tipo de mezclas, cementos con escorias de altos hornos, que cumplen con ASTM C 595-97 (11). Los pesos específicos de los áridos finos, medios y gruesos, fueron, respectivamente, de 2,67, 2,68 y 2,68. El módulo de finura de la arena era de 3,64. El tamaño de la grava gruesa y de los áridos de tamaño medio era de 20 y $9,5 \mathrm{~mm}$, respectivamente. Todos los áridos utilizados eran de piedra caliza machacada y su composición granulométrica, era conforme a ASTM C 33-93 (12). Con el fin de mejorar la trabajabilidad del hormigón, sc utilizó un aditivo reductor de agua, añandiéndose un 10\% de humo de sílice por peso de cemento. Todas las dosificaciones de hormigón incluyen cemento de escoria, agua, superplastificantes, grava y áridos finos con un contenido de 550,0,190,6, 16,5, 1.066,0 y 710,0 $\mathrm{kg} / \mathrm{m}^{3}$, respectivamente.

\subsection{Fibras de acero}

Para llevar a cabo esta investigación se utilizaron fibras de acero en haces, con extremos en forma de gancho y tres diferentes medidas (l/d: longitud /diámetro), de 60,75 y 83 . Las longitudes y diámetros de los tres tipos de fibras, eran de $30,60,50 \mathrm{~mm}$ y $0,50,0,80$, $0,60 \mathrm{~mm}$, respectivamente. Se añadieron, asimismo, cuatro volúmenes de fibras a cada amasada, con un porcentaje del $0,5,1,0,1,5$ y 2,0 por volumen de hormigón $\left(39,25 \mathrm{~kg} / \mathrm{m}^{3}, 78,50 \mathrm{~kg} / \mathrm{m}^{3}, 117,75 \mathrm{~kg} / \mathrm{m}^{3} \mathrm{y}\right.$ $\left.157,00 \mathrm{~kg} / \mathrm{m}^{3}\right)$.

\subsection{Experimentos sobre hormigón fresco}

La trabajabilidad de la mezcla de hormigón fresco se evaluó a través de la utilización de un Consistómetro $\mathrm{VeBe}$, de acuerdo con BS 1881: part. 104 (13). El contenido de aire se midió utilizando el método de presión, conforme con ASTM C 231-91b (12). Asimismo, se aplicó el procedimiento de curado estándar definido en BS 1881: part. 111. (14), y todas was determined by using the simple and economical drop-weight impact testing machine developed in this paper which can be used also on a construction site. On the other hand, a sophisticated closed-loop, servo controlled compression and flexural testing machine (200 kN flexural capacity) was used for determining the flexural toughness energy for the HSFRC composites. In this investigation, the authors have attempted to obtain a relationship between these two important properties.

\section{EXPERIMENTAL PROGRAM}

\subsection{Concrete}

The free water-cement ratio used for this investigation was 0.35. Blast-furnace slag cement complying with ASTM C 595-97 (11) was used in all mixes. The specific gravities of the fine, medium and coarse aggregates were 2.67, 2.68 and 2.68, respectively. The fineness modulus of the fine aggregate was 3.64. The maximum sizes of coarse and medium aggregates were 20 and $9.5 \mathrm{~mm}$, respectively. All the aggregates used were crushed limestone and their gradings complied with ASTM C 33-93 (12). To improve the workability of concrete, high range water-reducing admixture was used. Silica fume was added at $10 \%$ by weight of cement. All concrete mixtures include blast-furnace slag cement, water, superplasticizer, coarse aggregate, and fine aggregate contents, in $\mathrm{kg} / \mathrm{m}^{3}$, of 550.0 , 190.6, 16.5, 1066.0, and 710.0, respectively.

\subsection{Steel fibers}

Steel fibers used in this investigation were hookedend bundled fibers with three different aspect ratios (l/d: length over diameter ratio) of 60,75 and 83. The lengths and diameters of three types of fibers were $30,60,50 \mathrm{~mm}$ and $0.50,0.80,0.60 \mathrm{~mm}$, respectively. Four different fiber volumes were added to each series of mixes at 0.5, 1.0, 1.5 and $2.0 \%$ by volume of concrete (i.e. $39.25 \mathrm{~kg} / \mathrm{m}^{3}, 78.50$ $\mathrm{kg} / \mathrm{m}^{3}, 117.75 \mathrm{~kg} / \mathrm{m}^{3}$ and $157.00 \mathrm{~kg} / \mathrm{m}^{3}$ ).

\subsection{Experiments on fresh concrete}

The workability of freshly mixed concrete was assessed by using VeBe Consistometer in accordance with BS 1881: part 104 (13). Air content was measured by using the pressure method according to ASTM C 231-91b (12). Standard curing procedure defined in BS 1881: part 111. (14) was applied, and 
las muestras se compactaron en moldes con la ayuda de una mesa de vibrado.

\subsection{Ensayos de compresión}

El ensayo se llevó a cabo sobre 6 probetas cilíndricas de $150 \times 300$, ensayadas tras 28 días de curado, con el fin de obtener un valor medio para cada ensayo.

\subsection{Pruebas de resistencia al impacto}

El ensayo se llevó a cabo sobre probetas cilíndricas de $150 \mathrm{~mm}$ de diámetro y $60 \mathrm{~mm}$ de largo, cortadas a partir de probetas cilíndricas de $150 \times 300 \mathrm{~mm}$ de diámetro con la ayuda de una sierra de albañilería. Se ensayaron doce cilindros con cl fin de obtener la media de golpes necesarios hasta la aparición de la primera grieta visible y la rotura total al cabo de 28 días. La máquina de impacto, tipo martinete, se desarrolló modificando la máquina de prucbas de impacto de áridos original, de acuerdo con BS 812: part. 112 (15). El desarrollo del aparato de ensayos tipo martinete puede verse en la Figura 1 . El peso del martillo es de $13,5 \mathrm{~kg}$ y su altura de $30 \mathrm{~cm}$. Durante el impacto, se midió la velocidad del martillo, que resultó ser de $1,8088 \mathrm{~m} / \mathrm{s}\left(\mathrm{V}_{1}\right)$. La energía de impacto liberada, en relación con la muestra producida por cada golpe, se calculó de la forma siguiente: all the specimens were compacted in molds by means of a vibrating table.

\subsection{Compressive strength tests}

The test was performed on $150 \times 300 \mathrm{~mm}$ cylinders. Six cylinders were tested for 28 days after casting to obtain an average value for each test.

\subsection{Impact resistance tests}

The test was performed on $150 \mathrm{~mm}$ diameter $x 60 \mathrm{~mm}$ long cylinders cut from $150 \times 300 \mathrm{~mm}$ diameter cylinders by using a masonry saw. Twelve cylinders were tested to obtain the average number of blows required to cause the first visible crack and the ultimate failure at 28 days age. The drop weight type impact test machine was developed by modifying the original aggregate impact testing machine in accordance with BS 812: part. 112 (15). The developed drop-weight type test apparatus is shown in Figure 1. The weight of the drop hammer is 13.5 $\mathrm{kg}$, the height of drop is $30 \mathrm{~cm}$. During the impact, the speed of the drop hammer is measured, and it was found as $1.8088 \mathrm{~m} / \mathrm{s}\left(V_{1}\right)$. The impact energy delivered to the specimen produced by each blow is calculated as follows:

donde:

$\mathrm{E}_{\mathrm{l}}=$ energía de impacto $(\mathrm{N}-\mathrm{m})$

$\mathrm{M}=$ peso del martinete $(\mathrm{kg})$

$\mathrm{V}_{\mathrm{l}}=$ velocidad del impacto $(\mathrm{m} / \mathrm{s})$

$\mathrm{N}=$ númcro de golpes

$$
\mathrm{E}_{1}=\frac{1}{2} \cdot \mathrm{M} \cdot \mathrm{V}_{1}^{2} \cdot \mathrm{N}
$$

where:

$E_{1}=$ impact energy $(N-m)$

$M=$ weight of the drop hammer $(\mathrm{kg})$

$V_{1}=$ impact speed $(\mathrm{m} / \mathrm{s})$

$N=$ number of blows

\subsection{Flexural toughness tests}

The tests were performed on 100x100x500 mm beams by using four points loading with supports $400 \mathrm{~mm}$ apart according to ASTM C 1018 (12). Six beams were tested for each series at age of 28 days. Flexural toughness was calculated as the area under the load-deflection curve $(N-m)$. The loading was displacement controlled at a rate of $0.06 \mathrm{~mm} / \mathrm{minute}$ and both the flexural load and load-point deflections were measured throughout the test. Energy absorption at a beam deflection of $3.5 \mathrm{~mm}$ was measured for all the beams tested in order to use the maximum area under the load-deflection curve, and 


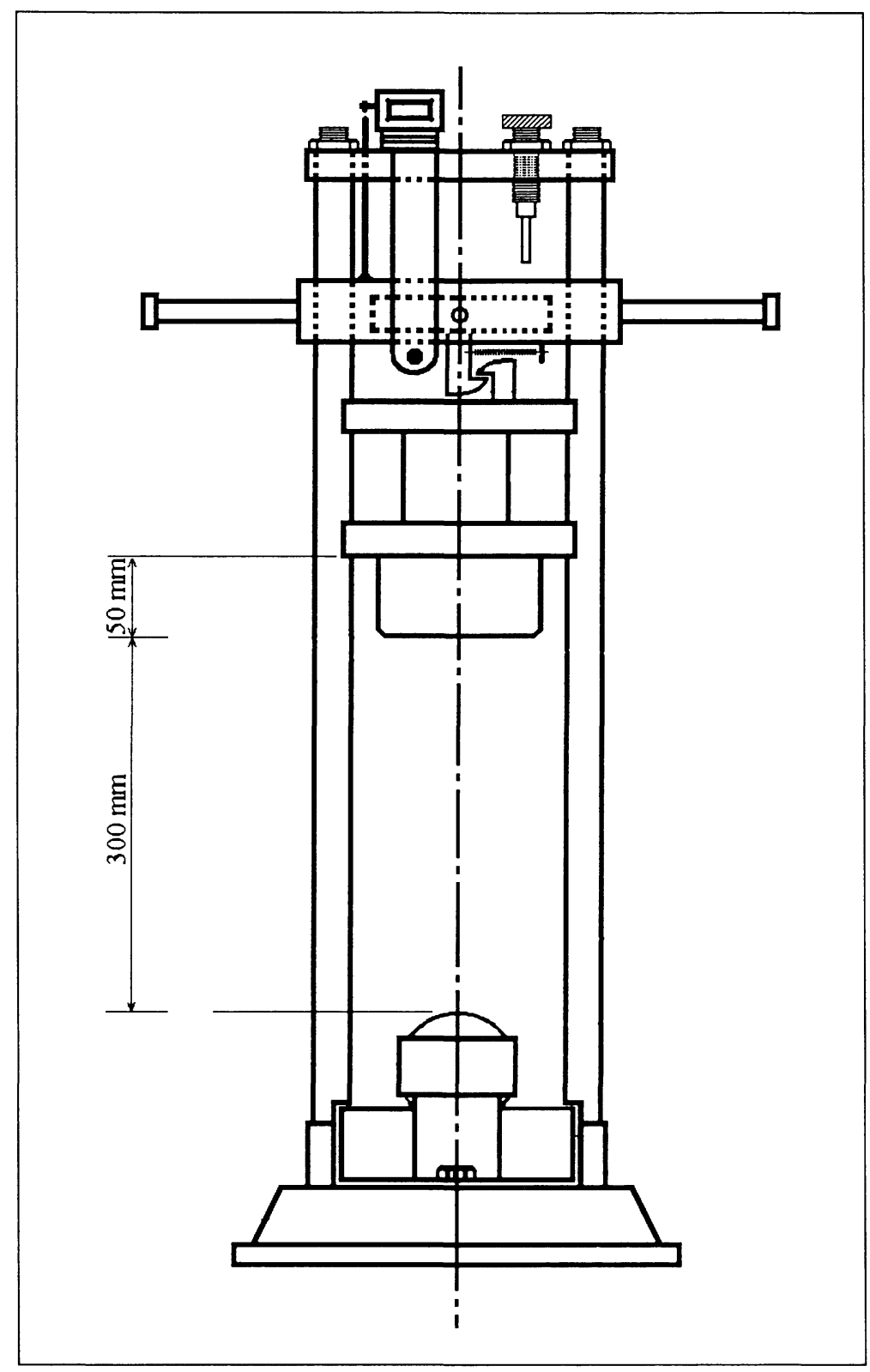

Figura 1.- Máquina para pruebas de impacto.

Figure 1.- Impact testing machine.

utilizar el área máxima bajo la curva de cargadeformación, dado que ASTM C 1018 permite la extensión racional del índice de tenacidad a índices mayores como $\mathrm{I}_{100}$ (16). De esta forma, se tomó dicho valor $\mathrm{I}_{100}$ (con una flecha o deformación aproximada de 3,5 mm) como límite máximo en la investigación. Otros investigadores (17) midieron la energía de absorción con una flecha por viga de $2,0 \mathrm{~mm}$, recomendando la utilización de mayores índices de tenacidad, como en $\mathrm{I}_{60}$.

\section{RESULTADOS Y DISCUSIÓN}

El resultado, tanto de la prueba de tiempo VeBe, como del contenido de aire, resistencia a flexión y resistencia a compresión del HSFRC, se muestran en la Tabla 1. also since ASTM C 1018 allows extension of the toughness index rationale to greater indexes, $I_{100}$ (16), so that this value $I_{100}$ (approximately at a deflection of $3.5 \mathrm{~mm}$ ) was taken as an upper limit in this research. Other researchers (17) have measured energy absorption at a beam deflection of $2.0 \mathrm{~mm}$ and recommended to use a higher toughness indexes such as $I_{60}$.

\section{RESULTS AND DISCUSSION}

The test results of VeBe time, air content, flexural strength, and compressive strength of the HSFRC are shown in Table 1. 
TABLA $1(T A B L E$ l)

Resultados del tiempo VeBe, contenido de aire, resistencia a compresión $\left.\mathrm{f}_{c}\right)$, resistencia a flexión $\left(\mathrm{f}_{t}\right)$, energía de impacto $\left(\mathrm{E}_{1}\right)$ y tenacidad a flexión $\left(\mathrm{T}_{\mathrm{ET}}\right)$ a los 28 días

Test results of VeBe time, air contant, compressive strength $\left(f_{c}^{\prime}\right)$, flexural stregth $(f)$ impact energy $\left(E_{l}\right)$ and flexural toughness $(E T)$ energy at 28 days

\begin{tabular}{|c|c|c|c|c|c|c|c|c|c|}
\hline \multirow{2}{*}{$\begin{array}{l}\text { 1/d } \\
\text { Relación } \\
\text { (Ratio) }\end{array}$} & \multirow{2}{*}{$\begin{array}{c}\text { Volumen } \\
\text { de fibras } \\
\text { (Volume } \\
\text { of fibers) } \\
\quad(\%)\end{array}$} & \multirow{2}{*}{$\begin{array}{c}\text { Tiempo } \\
\text { (VeBe) } \\
(\mathrm{s}) \\
\text { (VeBe } \\
\text { Time) } \\
(s)\end{array}$} & \multirow{2}{*}{$\begin{array}{l}\text { Contenido } \\
\text { de aire } \\
\text { (Air } \\
\text { content) } \\
(\%)\end{array}$} & \multirow{2}{*}{$\begin{array}{c}\mathrm{f}_{\mathrm{c}} \\
(\mathrm{MPa})\end{array}$} & \multirow{2}{*}{$\begin{array}{c}f_{t} \\
(\mathrm{MPa})\end{array}$} & \multicolumn{2}{|c|}{$\begin{array}{l}\text { Resistencia al impacto } \\
\text { (Número de golpes) } \\
\text { (Impact resistance } \\
\text { Number of blows)) }\end{array}$} & \multirow{2}{*}{$\begin{array}{c}\mathrm{E}_{1} \\
\text { Rotura total } \\
\text { (Complete failure) } \\
\mathrm{N}-\mathrm{m}(\text { C.O.V.)* }\end{array}$} & \multirow{2}{*}{$\begin{array}{c}\mathrm{E}_{\mathrm{ET}} \\
\text { en } 3,5 \mathrm{~mm} \\
(\text { at } 3.5 \mathrm{~mm} \text { ) } \\
\mathrm{N}-\mathrm{m}(\text { C.O.V.)* }\end{array}$} \\
\hline & & & & & & $\begin{array}{l}\text { Primera } \\
\text { grieta } \\
\text { (First } \\
\text { krack) }\end{array}$ & $\begin{array}{l}\text { Rotura } \\
\text { total } \\
\text { (Complete } \\
\text { failure) }\end{array}$ & & \\
\hline -.. & 0,0 & 3,7 & 0,95 & 74,5 & 9,903 & 4 & 5 & $110,4(0,2059)$ & $153(0.0747)$ \\
\hline 60 & 0,5 & 4,0 & 0,95 & 82,2 & 11,456 & 8 & 18 & $397,5(0,1404)$ & $34,8(0,0785)$ \\
\hline 60 & 1,0 & 8,5 & 0,80 & 82,8 & 12,580 & 22 & 45 & $993,8(0,0890)$ & $53,2(0,0600)$ \\
\hline 60 & 1,5 & 12,7 & 0,80 & 84,6 & 12,780 & 40 & 75 & $1656,3(0,0768)$ & $68,6(0,0634)$ \\
\hline 60 & 2,0 & 16,4 & 0,65 & 85,9 & 12,973 & 101 & 192 & $4240,0(0,0913)$ & $81,3(0,0450)$ \\
\hline 75 & 0,5 & 2,7 & 0,90 & 80,4 & 9,875 & 17 & 37 & $817,1(0,1013)$ & $50,2(0,0860)$ \\
\hline 75 & 1,0 & 13,8 & 0,80 & 82,5 & 10,649 & 29 & 56 & $1236,7(0,0722)$ & $61,7(0,0669)$ \\
\hline 75 & 1,5 & 14,2 & 0,80 & 84,2 & 11,370 & 43 & 151 & $3334,6(0,0874)$ & $87,4(0,0812)$ \\
\hline 75 & 2,0 & 94,6 & 0,70 & 87,9 & 12,342 & 116 & 276 & $6095,0(0,0670)$ & $103,5(0,0329)$ \\
\hline 83 & 0,5 & 5,6 & 1,05 & 82,2 & 11,751 & 21 & 48 & $1060,0(0,0971)$ & $52,4(0,0954)$ \\
\hline 83 & 1,0 & 9,0 & 0,95 & 83,9 & 12,415 & 33 & 68 & $1501,7(0,0905)$ & $62,9(0,0673)$ \\
\hline 83 & 1,5 & 15,7 & 0,80 & 86,0 & 14,863 & 81 & 172 & $3798,3(0,0876)$ & $108,6(0,0732)$ \\
\hline 83 & 2,0 & 102,2 & 0,65 & 87,3 & 16,611 & 193 & 373 & $8237,1(0,0346)$ & $138,8(0,0304)$ \\
\hline
\end{tabular}

* Coeficiente de variación

(Coefficient of variation) 


\subsection{Resultados del ensayo de resistencia al impacto}

El resultado de los ensayos de resistencia al impacto y las energías de impacto calculadas para el HSFRC, se dan en la Tabla 1. Al aumentar el contenido de fibra aumenta también la resistencia al impacto para todo tipo de fibras. Un volumen de fibra de $2,0 \%$ y relaciones $\mathrm{l} / \mathrm{d}(60,75$ y 83$)$, aumentan la resistencia al impacto respecto al hormigón sin fibras en más de 38 , 55 y 75 veces, respectivamente.

\subsection{Resultados del ensayo de tenacidad a flexión}

A medida que aumenta el volumen de fibra, crece, asimismo, la tenacidad. Cuando la relación $1 / \mathrm{d}$ aumenta de 60 a 83; la tenacidad parece ser mucho más pronunciada. El máximo aumento en la tenacidad fue del $68 \%$, con relación de aspecto o esbeltez medio de 83 y un volumen en porcentaje de fibra del $2,0 \%$, si se le compara con el hormigón simple. La tenacidad del HSFRC también aumentó a medida que crecían, tanto el contenido de fibra, como la esbeltez. $\mathrm{Al}$ añadir un 2,0\% de volumen, con una relación media de 60,75 y 83 , se aumenta la tenacidad frente al hormigón simple en 53 , 68 y 91 veces, respectivamente.

\subsection{Comparación entre energía de impacto y tenacidad a flexión}

Los dos principales factores que afectan a la resistencia última, por cuanto al hormigón reforzado con fibras se refiere, son el porcentaje de fibras utilizado y la relación $/ \mathrm{d}$. La energía de impacto y la tenacidad dan los máximos valores para una valor de 83 y un contenido de fibra de $0,5,1,0,1,5$ y $2,0 \%$. Esto puede ser debido al hecho de que se ha utilizado un máximo de fibras, de una longitud razonable, con el fin de paliar las micro-grietas y retrasar la aparición de grietas inestables.

La relación entre la energía de impacto y la tenacidad se muestra en la Figura 2 para las fibras de acero con esbelteces de 60,75 y 83 . Como puede verse también en la Figura 2, a medida que aumenta el contenido de fibra, aumentan, asimismo, la energía de fractura y la energía de impacto. La Figura 2 muestra, por tanto, una relación, logarítmica, entre la energía de impacto y la energía de fractura.

Para relaciones de forma de la fibra, de 60, 75 y 83; los análisis de regresión nos indican que existe, asimismo, una relación logarítmica entre la energía de fractura $\left(E_{F T}\right)$ y la energía de impacto $\left(E_{1}\right)$, como puede verse a continuación:

\subsection{Impact resistance test results}

Results of impact resistance tests and calculated impact energies of HSFRC are given in Table 1. Increasing the fiber content increases the impact resistance for all types of fibers. A 2.0\% fiber volume and an aspect ratio of 60,75, and 83 increased the impact resistance of plain concrete by up to 38,55 , and 75 times, respectively.

\subsection{Flexural toughness test results}

As the volume of fibers increases, the flexural strength also increases. As the aspect ratio increases from 60 to 83, the increase in flexural strength seems to be more pronounced. The highest increase in flexural strength was found to be $68 \%$ with an aspect ratio of 83 and a fiber volume percentage of $2.0 \%$ compared to plain concrete. The flexural toughness of HSFRC also increases as both fiber content and aspect ratio increase. Adding $2.0 \%$ fibers by volume at an aspect ratio of 60,75, and 83 increased the flexural toughness of plain concrete by 53, 68, and 91 times, respectively.

\subsection{Comparison between impact energy and flexural toughness energy}

The two most important factors that affect the ultimate strength for fiber reinforced concrete are the volume percentage of fibers and l/d ratio. Impact energy and flexural toughness energy gave the highest values for $1 / d$ ratio of 83 at a fiber content $0.5,1.0,1.5$ and $2.0 \%$. This could be due to the fact that, the number of fibers at a reasonable length to arrest microcracks and delay development of unstable crack system is the highest.

The relationship between impact energy and flexural toughness is shown in Figure 2 for steel fibers with aspect ratios of 60,75 and 83. As it can be seen from Figure 2 as the fiber content increases the flexural toughness energy as well as the impact energy increases. From Figure 2, the relationship between impact energy and flexural toughness energy is seems to be a logarithmic relationship.

For fiber aspect ratios of 60,75 and 83, regression analyses provided a logarithmic relationship between flexural toughness energy $\left(E_{F T}\right)$ and impact energy $\left(E_{1}\right)$ as shown below, respectively: 


$$
\begin{aligned}
& \mathrm{E}_{\mathrm{FT}(60)}=23.748 \ln \left(\mathrm{E}_{\mathrm{l}} / \mathrm{E}_{10}\right) \\
& \mathrm{E}_{\mathrm{FT}(75)}=25.653 \ln \left(\mathrm{E}_{\mathrm{l}} / \mathrm{E}_{10}\right) \\
& \mathrm{E}_{\mathrm{FT}(83)}=29.405 \ln \left(\mathrm{E}_{\mathrm{l}} / \mathrm{E}_{10}\right)
\end{aligned}
$$

Donde $\mathrm{E}_{\mathrm{FT}}$ es la energía de fractura $(\mathrm{N}-\mathrm{m}), \mathrm{E}_{\mathrm{l}}$ la cnergía de impacto $(\mathrm{N}-\mathrm{m})$, y $\mathrm{E}_{10}$ la energía del impacto de la mezcla de control (hormigón sin fibras) $(\mathrm{N}-\mathrm{m})$. Los cocficientes de correlación para las ecuaciones $2,3, \mathrm{y}$ 4 son $0,9977,0,9998$, y 0,993 , respectivamente. where $E_{F T}$ is flexural toughness energy $(N-m), E_{l}$ is impact energy $(N-m)$, and $E_{10}$ is the impact energy of the control mix $(N-m)$. The correlation coefficients for Equations 2, 3, and 4 are 0.9977, 0.9998, and 0.993, respectively.

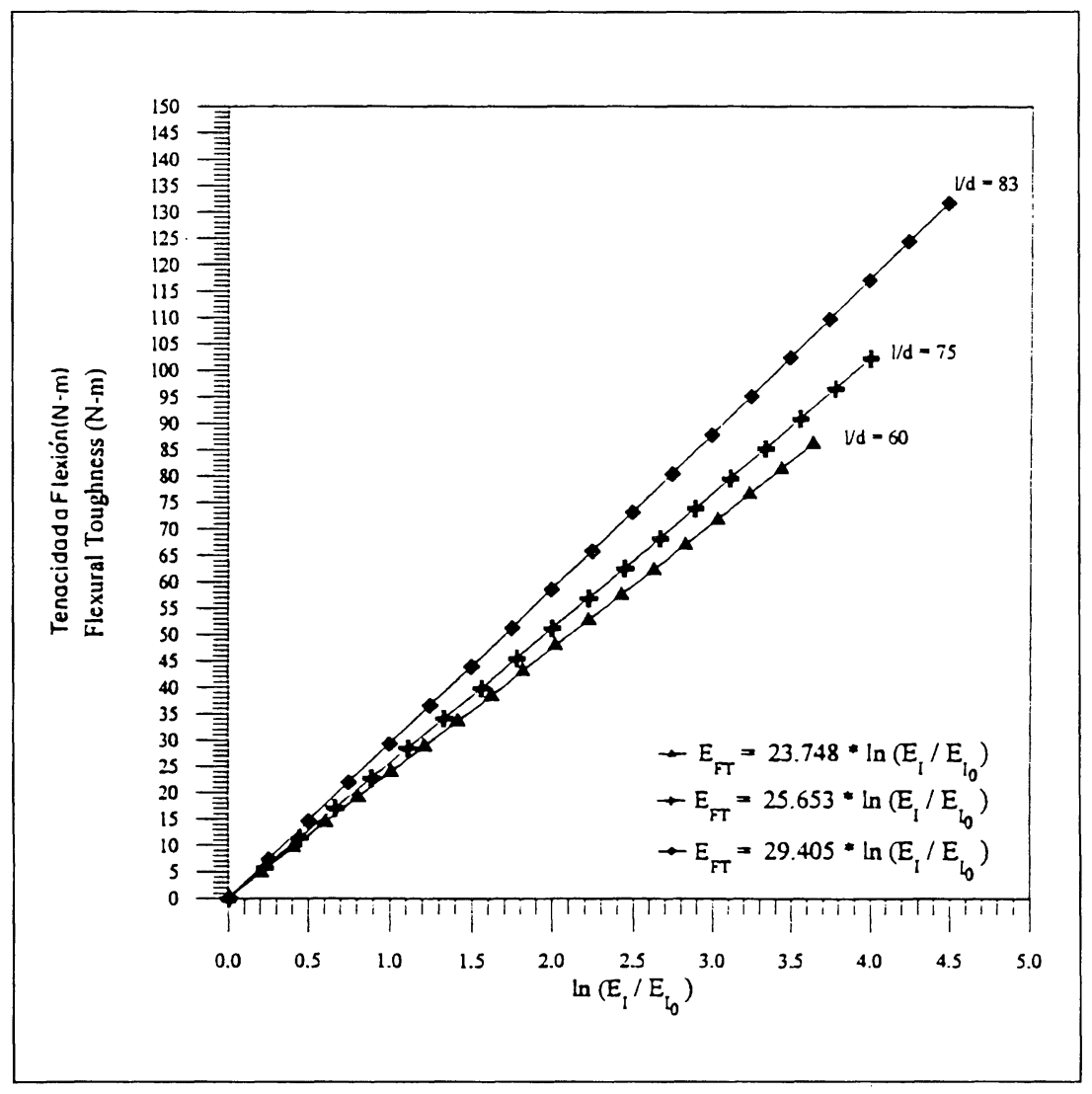

Figura 2.- Relación entre la energía de impacto y la tenacidad a flexión para valores de I/d de 60, 75 y 83 .

Figure 2.- Relationship between impact energy' and flexural toughness energy for lid of 60, 75 and 83.

\section{CONCLUSIONES}

A medida que se aumenta la cantidad de fibra, aumenta la resistencia al impacto. La resistencia al impacto del HSFRC, con un volumen de fibra en un porcentaje del $2 \%$ y una $\mathrm{I} / \mathrm{d}$ de 83 para un hormigón con $10 \%$ de humo de sílice, aumenta aproximadamente 91 veces si se compara con el hormigón sin fibras.

La relación entre la energía de impacto y la energía de fractura del HSFRC, para fibras con I/d de 60, 75 y 83 , se puede describir mediante una función logarítmica.

\section{CONCLUSIONS}

Increasing the amount of fiber leads to increase impact resistance. Impact resistance of HSFRC with a fiber volume percentage of $2 \%$ and an aspect ratio of 83 for $10 \%$ silica fume concrete increases to about 91 times to that of plain concrete.

A logarithmic function between flexural toughness energy and impact energy for fiber aspect ratio of 60,75 and 83 can describe the development of 
En general, los análisis de regresión tienen un buen coeficiente de correlación. Si la energía de impacto se obtiene utilizando aparatos de martinetes de repetición, la energía de fractura puede obtenerse fácilmente a través de las ecuaciones 2, 3 y 4 . Asimismo, con un simple ensayo de impacto (test de martinete), puede llegarse a calcular, fácilmente, la tenacidad del HSFRC, lo que hace que los ingenieros tiendan a utilizar HSFRC en aquellos casos en que la energía de absorción de la estructura es un factor especialmente importante. flexural toughness energy and impact energy of HSFRC. In general, the regression analyses give good correlation coefficients. If the impact energy is obtained by using simple repeated-drop weight apparatus, flexural toughness energy can be obtained easily from Equation 2, 3, and 4. It can be said that from a simple impact test (drop-weight test), flexural toughness energy of HSFRC can be calculated easily. This enables the engineers to use HSFRC in cases where energy absorption of the structure is especially important. 60,75 , and 83 .

\section{REFERENCIAS}

(1) FIP/CEB Report: High Strengh Concrete, State of the Art Report. Bulletin d'Information, FIP SR 90/1, No. 197, p. 61, London, 1990.

(2) P. Tjiptobroto, and W. Hansen: Tensile strain hardening and multiple cracking in high-performance cement-based composites containing discontinuous fibers. ACI Materials Journal, Vol. 90, №. 16(1993), pp. 16-25.

(3) V.S. Gopalaratnam, S.P. Shah, and R. John: $\Lambda$ modified instrumented charpy test for cement-based composites. Experimental Mechanics, Vol. 24, No. 2(1984), pp. 102-111.

(4)G. Wu, S. Shivaraj and V. Ramakrishnan: Fiber Reinforced Cements and Concretes. p. 261, Recent Developments, Edited by R.N. Swamy and B. Barr, Elsevier Applied Science, New York, 1989.

(5) T. Celik, T. and K. Marar: Effects of crushed stone dust on some properties of concrete. Cement and Concrete Research, Vol. 26, No. 7(1996),pp. 1121-1130.

(6) P. Soroushian, A. Tlili, A. Alhozaimy, and A. Khan: Development and Characterization of hybrid polyethylene-fiber reinforced cement composites. Construction and Building Materials, Vol. 7, N. 4(1993), pp. 221-229.

(7) V. Ramakrishnan, T. Brandshaug, W.V. Coyle, and E. Schrader: A comparative evaluation of concrete reinforced with straight steel fibers with deformed ends glued together into bundles. ACI Materials Journal, Vol. 77, No. 3 (1980), pp. 135-143.

(8) ACI Committee 544: measurement of properties of fiber-reinforced concrete. ACI Materials Journal, Vol. 85, N. 6(1988), pp. $583-593$.

(9) Z. Bayasi and T. Çelik: Applications of silica fume in synthetic fiber-reinforced concrete. Transportation Research Record, part. 2, $\mathrm{N}^{\circ}$ 1.382(1993),pp. 89-90.

(10) E.K. Scharader: Impact resistance and test procedure for concrete. $\Lambda$ CI Materials Journal, Vol. 78, No. 2 (1981), pp. $141-146$.

(11) American Society of Testing and Materials, Vol. 04.01, Cement;Lime;Gypsum (1997).

(12) American Society of Testing and Materials, Vol. 04.02, Concrete and Aggregates (1994)

(13) British Standards Institution, BSI, London, BS 1881: part. 104: 1983

(14)British Standards Institution, BSI, London, BS 812:part. 112:1990.

(16) V.S. Gopalarathnam, S.P. Shah, G.B. Batson, M.E. Criswell, V. Ramakrishnan, and M. Wecharatana:Fracture thoughness of fiber reinforced concrete. ACI Materials Journal, Vol. 99, No. 4 (1991), pp.339-353.

(17) J.F. Trottiere and N. Banthia: Thoughness characterization of Steel-fiber reinforced concrete. Journal of Materials in Civil Engineering, Vol. 6, No. 2(1994), pp. 264-289.

\section{Nota de la redacción}

El Comité de Redacción de la Revista Materiales de Construcción agradece a $\mathrm{D}^{\mathrm{a}}$ Stella Manaut la traducción del manuscrito, y al Ingeniero D. David Revuelta, la revisión técnica del artículo. 